\title{
Endophytic fungal diversity in coffee leaves (Coffea arabica) cultivated using organic and conventional crop management systems
}

\author{
Oliveira RJV ${ }^{1}$, Souza RGㅜㅗ Lima TEF $^{\mathbf{1}}$ and Cavalcanti MAQ ${ }^{1}$ \\ ${ }^{1}$ Departamento de Micologia, Universidade Federal de Pernambuco, Rua Nelson Chaves, s/ $n$, Cidade Universitária, \\ Recife, Pernambuco, 50670-901, Brazil, rafaelvilela87@gmail.com
}

Oliveira RJV, Souza RG, Lima TEF, Cavalcanti MAQ 2014 - Endophytic fungal diversity in coffee leaves (Coffea arabica) cultivated using organic and conventional crop management systems. Mycosphere 5(4), 523-530, Doi 10.5943/mycosphere/5/4/4

\begin{abstract}
Endophytic fungi dwell in the tissues of plants without causing disease symptoms. Coffee production can be performed using conventional or organic crop systems. Studies have been carried out to assess the endophytic fungal community in a conventional coffee crop system. However, little is known about them in organic conditions. Comparisons were made between an endophytic fungal community from leaves of Coffea arabica in organic and conventional crop systems. Mature and healthy leaves of $C$. arabica were collected from two crop systems during the wet and dry seasons, in the Northeast Brazil. A total of 432 fragments were analyzed and 336 specimens of endophytic fungi were isolated and distributed among 16 genera and 17 species. Colletotrichum gloeosporioides complex and Phyllosticta capitalensis were the most common fungi in conventional and organic crop systems, respectively. The largest number of fungal endophytes was observed during the wet season, although the diversity index and species richness were higher in the dry season. The endophytic fungal communities in conventional and organic crop systems exhibited $50.61 \%$ similarity, with six species occurring uniquely in organic and five in conventional coffee. Therefore, more research is needed to confirm that the species could be used as indicators of these management systems.
\end{abstract}

Key words - accumulation curves - Colletotrichum gloeosporioides complex - Phyllosticta capitalensis

\section{Introduction}

Fungal endophytes inhabit the tissues of plants without causing disease symptoms or external structural alterations (Azevedo \& Araujo 2007). These micro-organisms could improve the level of resistance to disease and abiotic stress, as well as favoring the growth of crop plants (Waller et al. 2005), producing bioactive substances (Lin et al. 2010, Selim et al. 2011) and exhibiting antagonistic (Rocha et al. 2011) and antimicrobial activity (Kharwar et al. 2010). Studies have been conducted with endophytes using species of plants that have economic significance, such as corn (Orole \& Adejumo 2011), coffee (Santamaria \& Bayman 2005, Vega et al. 2010), cocoa (Hanada et al. 2008), mango (Rondón \& Gozales 2009), wheat (Larran et al. 2007), and soybeans (Pimentel et al. 2006). Due to the interest in significant economic hosts, a number of endophytic fungal interactions have been studied in detail (Cheplick \& Faeth 2009). They have also been used in crop management strategies (Saunders et al. 2010). 
Brazil is a major coffee producer whose conventional production aims to meet economic interests. The organic system also aims to meet economic interests, although it is particularly focused on self-sustaining ecological and social interests (Nicoleli 2006, CONAB 2013). Organic coffee is treated with bio-fertilizers, organic bio-fertilizer or organic matter, whereas conventional production utilizes chemicals, pesticides and chemical fertilizers (Santos et al. 2010). The organic system has a higher cost for cultivation than conventional agriculture (Kapoulas et al. 2011). However, research has shown that a bag of coffee from an organic production system could be worth three times the value of the conventional product (Nicoleli 2006).

Studies of endophytic fungi in coffee were pioneered by Rayner (1948) and were followed by Santamaría \& Bayman (2005) and Vega et al. (2006, 2010). However, there are no reports about the composition of this community on healthy leaves of Coffea arabica L. in an organic system. The aim of the present study was to present the results of the ecological relationship between endophytic fungal communities from healthy leaves of $C$. arabica in organic and conventional crop systems in Brazil, considering that these communities exhibited differences in species composition.

\section{Materials \& Methods}

\section{Leaf sampling, isolation and identification of fungi}

Mature and healthy leaves of Coffea arabica were collected in two systems (conventional and organic coffee) in the municipality of Garanhuns, Pernambuco, Brazil ( $8^{\circ} 57^{\prime} 24^{\prime \prime}$ S and 36 32'44" W). The crop systems had an area of approximately 1.5 hectares. Between July of 2010 and April of 2011, four collections were carried out, two of which were in the dry season (October and January), while the other two were performed during the rainy season (July and April). For each system nine coffee trees were determined in three random points. Six healthy leaves were collected in each plant.

In total, 432 leaves were obtained and the samples were manipulated in a maximum time of 24 hours. In the laboratory, 432 leaf discs were cut with a sterile metallic cork punch $(6 \mathrm{~mm} \mathrm{diam}$.), decontaminated with $70 \%$ alcohol for 30 seconds and hypochlorite sodium solution $(\mathrm{NaOCl})$ at $2 \%$ for 2.5 minutes. They were then washed twice with sterilized distilled water in order to remove excess hypochlorite (Petrini 1996, modified technique). Six surface sterilized discs were transferred in triplicate to each Petri dish containing Agar-Malte (MEA) + chloramphenicol (50 mg.L-1) to prevent bacterial growth. The plates were incubated at room temperature $\left(28 \pm 2^{\circ} \mathrm{C}\right)$ and observed daily for 15 days for colony development. For identification of endophytic filamentous fungi, micro-cultivations were performed, and the macro and micro morphological aspects of the somatic and reproductive structures were observed, using specific methodology and literature (Ellis 1971, 1976, Sutton 1980, Domsch et al. 1993).

\section{Data analysis}

The relative abundance of the species was calculated and the similarity between the fungal communities was estimated using Sorensen's Index (Brower \& Zar 1984). The Shannon and Margalef diversity indices and the Pielou evenness index were calculated for each system. The Shannon diversity index ( $\left.\mathrm{H}^{\prime}\right)$ was calculated using the following equation: $\mathrm{H}^{\prime}=-\sum$ (Pi $\left.\ln [\mathrm{Pi}]\right)$; where $\mathrm{Pi}=\mathrm{ni} / \mathrm{N}, \mathrm{ni}=$ number of individuals of the species $\mathrm{i}$, and $\mathrm{N}=$ total number of individuals of all species. The Margalef index was calculated using the equation: $d=S-1 / \operatorname{LogN}$, where $S$ is the number of species and $\mathrm{N}$ is the total number of specimens in the sample. The Pielou evenness result was obtained using the equation: J' $=\mathrm{H}^{\prime} / \log (\mathrm{S})$, where $\mathrm{H}^{\prime}$ is the value obtained by the Shannon index and $S$ is species richness. Diversity indices were determined using the past program (Hammer et al. 2001). Species accumulation curves were also estimated for the organic and conventional crop systems (Jackknife 1 and Bootstrap) using Primer 6.0 software (Clarke \& Gorley 2006). 


\section{Results}

\section{Diversity of endophytic fungi in coffee}

A total of 432 fragments were analyzed and 336 endophytic fungi specimens were isolated and distributed among 16 genera and 17 species (Table 1). The most common species in conventional and organic coffee systems were Colletotrichum gloeosporioides complex (27.3\%), Phyllosticta capitalensis (= Guignardia mangiferae) $(26.1 \%)$ and C. gloeosporioides (= Glomerella cingulata) (23.2\%). Others such as Cladosporium cladosporioides complex (5.05\%), Colletotrichum coffeanum (2.97\%) and Xylaria sp. (2.3\%) were less common. Aureobasidium pullulans, Cladosporium tenuissimum, Diaporthe liquidambari, D. phaseoli, Drechslera biseptata, Lasiodiplodia pseudotheobromae, Khuskia oryzae, Nodulisporium gregarium, Pestalotiopsis maculans, Phoma eupyrena, Phyllosticta sp., Rhodotorula aurantiaca and Sarocladium bacillisporum exhibited a low abundance $(\leq 2 \%)$. A number of fungal isolates which produced no reproductive structures remained mycelia sterilia $(4.46 \%)$.

Table 1 Endophytic fungi isolated from organic and conventional crop management systems in the northeast of Brazil.

\begin{tabular}{|c|c|c|c|c|}
\hline \multirow[t]{2}{*}{ Endophytic fungi } & \multicolumn{2}{|c|}{ Conventional Coffee } & \multicolumn{2}{|c|}{ Organic Coffee } \\
\hline & $\mathbf{N}^{\mathbf{a}}$ & $\mathbf{F r}^{\mathbf{a}}$ & $\mathbf{N}$ & Fr \\
\hline Aureobasidium pullulans & 5 & 2.94 & 0 & 0 \\
\hline Cladosporium cladosporioides complex & 12 & 6.81 & 5 & 3.12 \\
\hline C. tenuissimum & 3 & 1.70 & 0 & 0 \\
\hline Colletotrichum coffeanum & 7 & 3.97 & 3 & 1.87 \\
\hline C. gloeosporioides complex & 67 & 38.06 & 29 & 18.12 \\
\hline C. gloeosporioides $(=$ Glomerella cingulata $)$ & 36 & 20.45 & 42 & 26.2 \\
\hline Diaporthe liquidambaris & 0 & 0 & 2 & 1.25 \\
\hline D. phaseoli & 1 & 0.56 & 0 & 0 \\
\hline Drechslera biseptata & 0 & 0 & 1 & 0.62 \\
\hline Khuskia oryzae & 1 & 0.56 & 1 & 0.62 \\
\hline Lasiodiplodia pseudotheobromae & 0 & 0 & 1 & 0.62 \\
\hline Nodulisporium gregarium & 0 & 0 & 1 & 0.62 \\
\hline Pestalotiopsis maculans & 0 & 0 & 1 & 0.62 \\
\hline Phyllosticta capitalensis (= Guignardia mangiferae) & 32 & 18.18 & 56 & 35 \\
\hline Phyllosticta sp. & 1 & 0.56 & 3 & 1.87 \\
\hline Phoma eupyrena & 0 & 0 & 1 & 0.62 \\
\hline Rhodotorula aurantiaca & 1 & 0.56 & 0 & 0 \\
\hline Sarocladium bacillisporum & 1 & 0.62 & 0 & 0 \\
\hline Xylaria sp. & 3 & 1.70 & 5 & 3.12 \\
\hline Mycelia sterilia & 6 & 3.40 & 9 & 5.62 \\
\hline Total & 176 & & 160 & \\
\hline
\end{tabular}

$\mathrm{N}=$ Number of isolates $\mathrm{Fr}=$ Relative frequency of isolates

\section{Endophytic fungi diversity by sampling period}

Upon comparing the sampling periods, a greater abundance of endophytic fungi was observed in the wet season. However, the highest species richness was in the two cropping systems in the dry season (Table 2). Shannon's and Margalef's indices were higher during the dry season than in the rainy season. Eleven out of the 17 species only occurred during the dry period: Aureobasidium pullulans, Cladosporium cladosporioides complex, C. tenuissimum, Diaporthe liquidambari, Drechslera biseptata, Khuskia oryzae, Nodulisporium gregarium, Phoma eupyrena, Pestalotiopsis maculans, Rhodotorula aurantiaca and Sarocladium bacillisporum. 
Table 2 Species richness (S), number of individuals $(\mathrm{N})$, Shannon's diversity indices ( $\left.\mathrm{H}^{\prime}\right)$, Margalef's $(d)$ and Pielou's index $\left(J^{\prime}\right)$ in conventional coffee $(\mathrm{CC})$ and organic coffee $(\mathrm{OC})$ during the rainy season $(\mathrm{R})$ and dry season $(\mathrm{D})$.

\begin{tabular}{lccccc}
\hline Area/Season & $\mathbf{S}$ & $\mathbf{N}$ & $\mathbf{H}^{\prime}$ & $\mathbf{D}$ & $\mathbf{J}$ \\
\hline CC R & 7 & 90 & $1.477 \mathrm{~b}$ & $1.333 \mathrm{~b}$ & 0.7592 \\
CC D & 13 & 76 & $1.933 \mathrm{a}$ & $2.933 \mathrm{a}$ & 0.7361 \\
OC R & 8 & 85 & $1.438 \mathrm{~b}$ & $1.576 \mathrm{~b}$ & 0.6916 \\
OC D & 14 & 75 & $2.054 \mathrm{a}$ & $3.453 \mathrm{a}$ & 0.745 \\
\hline
\end{tabular}

\section{Organic coffee vs. conventional coffee}

The species richness, abundance, evenness and diversity of endophytic fungi varied little between the two crops (Table 3). The similarity between the two crops was $50.61 \%$. The number species exclusive in organic or conventional were 6 and 5 respectively. Drechslera biseptata, Lasiodiplodia pseudotheobromae, Nodulisporium gregarium, Pestalotiopsis maculans, Phoma eupyrena, Rhodotorula aurantiaca and Sarocladium bacillisporum, occurring only once (Table 1). Colletotrichum gloeosporioides $(=$ Glomerella cingulata) and C. gloeosporioides complex exhibited a high frequency for conventional coffee, similar to Phyllosticta capitalensis and $C$. gloeosporioides for organic coffee (Table 1). According to the estimated Jackknife index, the species richness of conventional coffee was 70\% (Fig. 1) and of organic coffee was $75 \%$ (Fig. 2).

Table 3 Species richness (S), number of specimens (N), Shannon's diversity indices (H'), Margalef's (D) and Pielou's index ( $\left.\mathrm{J}^{\prime}\right)$ of endophytic fungi isolated from organic and conventional crop management techniques, regardless of the collection period.

\begin{tabular}{lccccc}
\hline Areas & S & N & H'$^{\prime}$ & D & J' \\
\hline Conventional Coffee & 14 & 176 & 1.816 & 2.514 & 0.688 \\
Organic Coffee & 15 & 160 & 1.801 & 2.759 & 0.665 \\
\hline
\end{tabular}

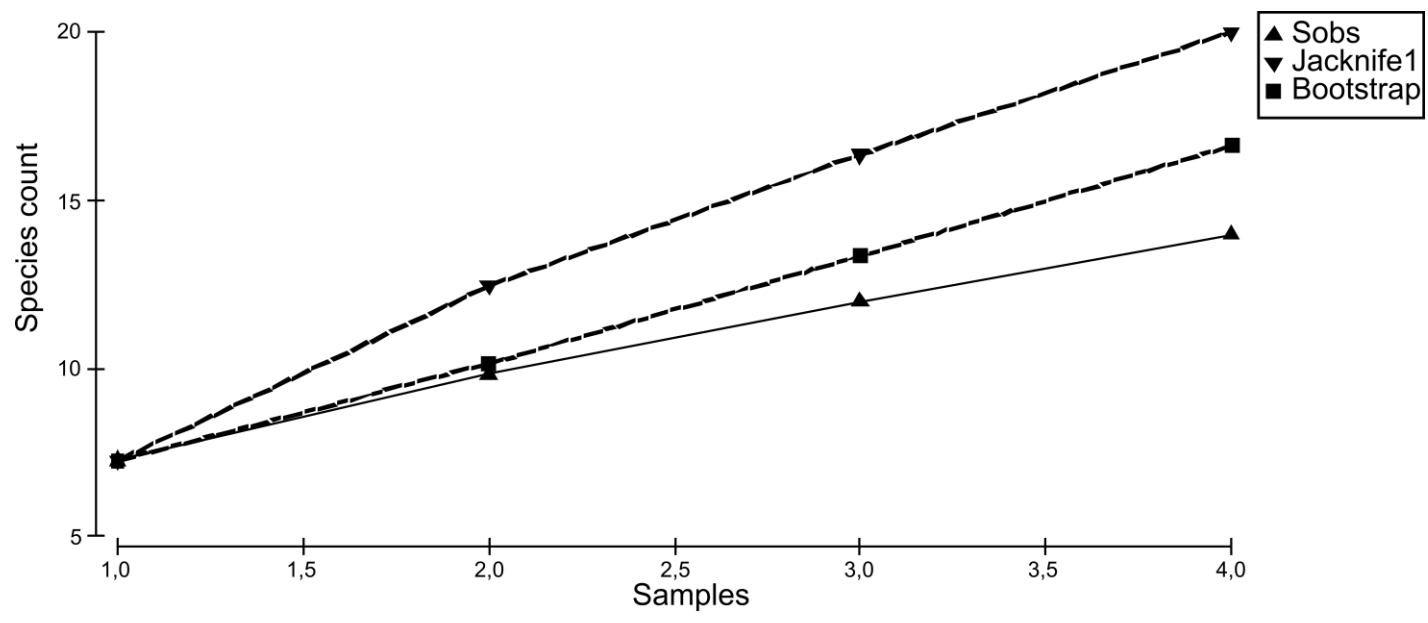

Fig. 1 - Species accumulation curves (Sobs) and estimated richness of conventional crop management using the Jackknife (Jackknife 1) and Bootstrap index. 


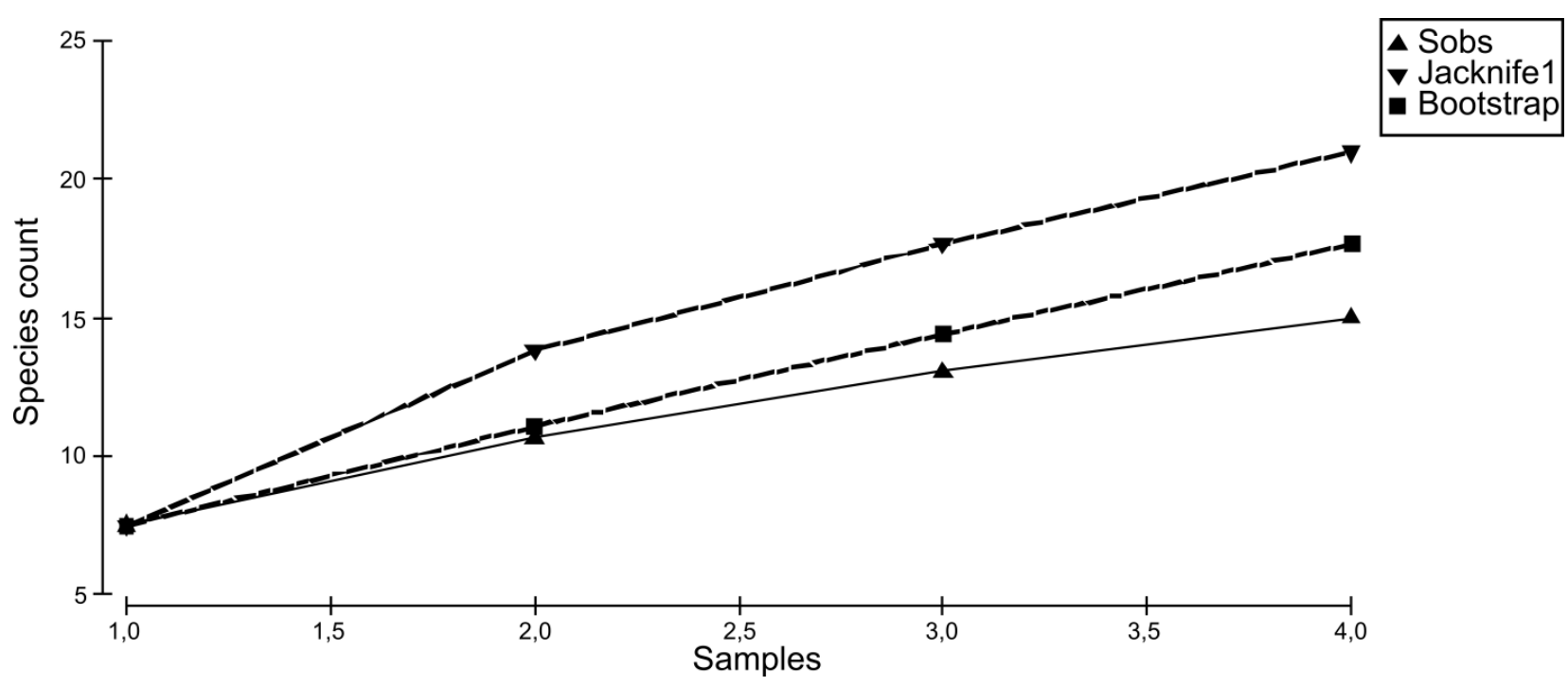

Fig. 2 - Species accumulation curves (Sobs) and estimated richness of organic crop management using the Jackknife (Jackknife 1) and Bootstrap index.

\section{Discussion}

Colletotrichum species are often reported as endophytic (Photita et al. 2005, Huang et al. 2008, Peng et al. 2013) and are found in various plants from tropical regions (Costa et al. 2012a). Colletotrichum was the most common genus in the present study, which was also reported by Vega et al. (2010) in seven species of Coffea. Santamaría and Bayman (2005) reported Xylaria and Colletotrichum as the most frequent endophytes in Coffea arabica. These authors observed no growth of Colletotrichum around leaf fragments containing Xylaria, suggesting a possible antagonistic relationship between Colletotrichum and Xylaria, similar to the findings of the present study. Colletotrichum coffeanum is an important phytopathogen responsible for anthracnose in coffee. In Kenya and other African countries, anthracnose is the main limiting factor of coffee production, which may entail a reduction in productivity between $50 \%$ and $80 \%$ (Griffiths et al. 1971). The present study recorded the first report of $C$. coffeanum as an endophyte on coffee leaves.

Guignardia mangiferae has been isolated as an endophyte from different hosts (Rodrigues et al. 2004). In tropical regions, Wickert et al. (2009) reported G. mangiferae as an endophyte in the leaves of orange, mango, guava, cherry and Brazilian grape trees. Santamaría \& Bayman (2005) reported Guignardia as an endophyte in the leaves of Coffea arabica.

The community of endophytic fungi may vary depending on the sampling period (Costa et al. 2012b). Differences were observed between sampling periods in the present study, with a higher abundance of endophytic fungi in the rainy season, and the most diverse fungi found during the dry season. The diversity indices also showed differences between sampling periods, with $58 \%$ of the species occurring exclusively in the dry season, indicating a strong influence of moisture on species composition. This fact suggests that with decreasing precipitation, the most abundant species decrease their growth and thus favor the emergence of other species, including those of rare occurrence.

Endophytic fungal communities displayed little variation in the indices of diversity, species richness and quantity of specimens, indicating that both organic and conventional coffee harbor similar numbers of individuals. However, Camatti-Sartori et al. (2005) showed that endophytic fungi from leaves of apple trees on an organic farm exhibited a higher number of isolates when compared with conventional cultivation. The variability across endophytic fungal communities in grapevines may be greater on organic farms (Pancher et al. 2012).

Interestingly, $60 \%$ of the species in organic coffee were teleomorphs. The reverse was observed for conventional coffee (40\%), indicating that organic conditions may favor the completion of the life cycle of certain species. Furthermore, the community of endophytic fungi in organic coffee was $50.61 \%$ similar to the conventional coffee crop. Approximately $40 \%$ of all 
species identified in the two systems were unique to each culture. Species of endophytic fungi may be used as indicators of these management systems (Camatti-Sartori et al. 2005). However, many of these species occurred only once. This fact is usual in studies of endophytes fungi therefore, should not be used as indicators of managements systems studied.

Considering the fact that the accumulation curve of species for both organic and conventional coffee did not reach the stabilization point, new collections are warranted to better assess the richness of fungal endophytes in coffee from different management systems. The present study showed that $C$. arabica harbors a considerable diversity of endophytic fungi in both managements systems, which was best represented in the dry season. Therefore, more research is needed in order to confirm that organic and conventional coffee are composed of different communities of endophytic fungi, and that the species may be used as indicators of these management systems.

\section{Acknowledgements}

The authors are thankful for the financial support provided by Conselho Nacional de Desenvolvimento Científico e Tecnológico (CNPq).

\section{References}

Azevedo JL, Araujo WL. 2007 - Diversity and applications of endophytic fungi isolated from tropical palnts. In: Ganguli BN, Deshmukh SK (eds), Multifaceted microbes. CRC press, Boca Raton, pp 189-207.

Brower JE, Zar JH. 1984 - Community similarity. In: Brower JE, Zar JH (eds), Field and laboratory for general ecology. Win C. Brown Publishers, Dubuque, pp 161-164.

Camatti-Sartori V, da Silva-Ribeiro RT, Valdebenito-Sanhueza RM, Pagnocca FC, Echeverrigaray S, Azevedo JL. 2005 - Endophytic yeasts and filamentous fungi associated with southern Brazilian apple (Malus domestica) orchards subjected to conventional, integrated or organic cultivation. Journal of Basic Microbiology 45, 397-402. http://dx.doi.org/10.1002/jobm.200410547.

Cheplick GP, Faeth SH. 2009 - Ecology and evolution of the grass-endophyte symbiosis. Oxford University Press, New York. http://dx.doi.org/10.1093/acprof:oso/9780195308082.001.0001.

Clarke KR, Gorley RN. 2006 - PRIMER v6: user manual/tutorial. PRIMER-E, Plymouth.

CONAB (Companhia Nacional de Abastecimento). 2013 - Acompanhamento da Safra Brasileira Café Safra 2013 primeira estimativa. CONAB, Brasília. http://www.conab.gov.br/OlalaCMS/uploads/arquivos/13_01_09_17_43_49_boletim_cafe_ja neiro_2013.pdf. Accessed: 24 Sep 2013.

Costa IPMW, Assunção MMC, Lima TEF, Oliveira RJV, Cavalcanti MAQ. 2012a - Checklist of endophytic fungi from tropical regions. Mycotaxon 119, 493-494. http://dx.doi.org/10.5248/119.493.

Costa IPMW, Maia LC, Cavalcanti MA. 2012b - Diversity of leaf endophytic fungi in mangrove plants of northeast Brazil. Brazilian Journal of Microbiology 43, 1165-1173. http://dx.doi.org/10.1590/S1517-83822012000300044.

Domsch KH, Gams W, Anderson TH. 1993 - Compendium of soil fungi. Verlag: IHW. 1264 p.

Ellis MB. 1971 - Dematiaceous Hyphomycetes. Commonwealth Mycological Institute, Kew. England. 608 p.

Ellis MB. 1976 - More Dematiaceous Hyphomycetes. Commonwealth Mycological Institute, Kew. England. 507 p.

Griffiths E, Gibbs JN, Waller JM. 1971 - Control of coffee berry disease. Annals of Applied Biology 67, 45-74. http://dx.doi.org/10.1111/j.1744-7348.1971.tb02907.x.

Hammer O, Harper DAT, Rian PD. 2001 - Past: palaeonthological statistics software package for $\begin{array}{llll}\text { education and da } & \text { analysis, } & \text { ver. } & 1.37\end{array}$ electronica.org/2001_1/past/issue1_01.htm. Accessed: 12 Sep 2005. 
Hanada RE, de Jorge Souza T, Pomella AWV, Hebbar KP, Pereira JO, Ismaiel A, Samuels GJ. 2008 - Trichoderma martiale sp. nov., a new endophyte from sapwood of Theobroma cacao with a potential for biological control. Mycological Research 112, 1335-1343. http://dx.doi.org/10.1016/j.mycres.2008.06.022.

Huang WY, Cai, YZ, Hyde KD, Corke H, Sun M. 2008 - Biodiversity of endophytic fungi associated with 29 traditional Chinese medicinal plants. Fungal Diversity 33, 61-75.

Kapoulas N, Ilić ZS, Đurovka M, Trajković R, Milenković L. 2011 - Effect of organic and conventional production practices on nutritional value and antioxidant activity of tomatoes. African Journal of Biotechnology 10, 15938-15945. http://dx.doi.org/10.5897/AJB11.904.

Kharwar RN, Gond SK, Kumar A, Mishra A. 2010 - A comparative study of endophytic and epiphytic fungal association with leaf of Eucalyptus citriodora Hook., and their antimicrobial activity. World Journal of Microbiology and Biotechnology 26, 1941-1948. http://dx.doi.org/10.1007/s11274-010-0374-y.

Larran S, Perello A, Simon MR, Moreno V. 2007 - The endophytic fungi from wheat (Triticum aestivum L.). World Journal of Microbiology and Biotechnology 23, 565-572. http://dx.doi.org/10.1007/s11274-006-9266-6.

Lin X, Huang YJ, Zheng ZH, Su WJ, Qian XM, Shen YM. 2010 - Endophytes from the pharmaceutical plant, Annona squamosa: isolation, bioactivity, identification and diversity of its polyketide synthase gene. Fungal Diversity 41, 41-51. http://dx.doi.org/10.1007/s13225010-0017-5.

Nicoleli M, Moller HD. 2006 - Análise da competitividade dos custos do café orgânico sombreado irrigado. Custos e @ gronegócio 1,29-44.

Orole OO, Adejumo TO. 2011 - Bacterial and fungal endophytes associated with grains and roots of maize. Journal of Ecology and the Natural Environment 3, 298-303.

Pancher M, Ceol M, Corneo PE, Longa CMO, Yousaf S, Pertot I, Campisano A. 2012 - Fungal endophytic communities in grapevines (Vitis vinifera L.) respond to crop management. $\begin{array}{llll}\text { Applied and } \quad \text { Environmental 4308-4317. } & \text { Microbiology }\end{array}$ http://dx.doi.org/10.1128/aem.07655-11.

Peng Li-J, Sun T, Yang You-L, Cai L, Hyde KD, Bahkali AH, Liu Zuo-Y. 2013 - Colletotrichum species on grape in Guizhou and Yunnan provinces, China. Mycoscience 54, 29-41. http://dx.doi.org/10.1016/j.myc.2012.07.006.

Petrini O. 1996 - Ecological and physiological aspects of host specific and endophytic fungi. In: Redli SC, Caris LM (eds), Endophytic fungi in grasses and woody plants: systematics, ecology and evolution. American Phytopatological Society Press, St. Paul, pp 87-100.

Photita W, Taylor PWJ, Ford R, Lumyong P, McKenzie EHC, Hyde KD, Lumyong S. 2005 Morphological and molecular characterization of Colletotrichum species from herbaceous plants in Thailand. Fungal Diversity 18, 117-133.

Pimentel IC, Glienke-Blanco C, Gabardo J, Stuart RM, Azevedo JL. 2006 - Identification and colonization of endophytic fungi from soybean (Glycine max (L.) Merril) under different environmental conditions. Brazilian Archives of Biology and Technology 49, 705-711. http://dx.doi.org/10.1590/S1516-89132006000600003.

Rayner RW. 1948 - Latent infection in Coffea arabica L. Nature 161, 245-246. http://dx.doi.org/10.1038/161245a0.

Rocha ACS, Garcia D, Uetanabaro APT, Carneiro RTO, Araújo IS, Mattos CRR, Góes-Neto A. 2011 - Foliar endophytic fungi from Hevea brasiliensis and their antagonism on Microcyclus ulei. Fungal Diversity 47, 75-84. http://dx.doi.org/10.1007/s13225-010-0044-2.

Rodrigues KF, Sieber TN, Grünig C, Holdenrider O. 2004 - Characterization of Guignardia mangiferae isolated from tropical plants based in morphology, ISSR-PCR amplifications and ITS1-5.8SITS2 sequences. Mycological Research 108, 45-52. http://dx.doi.org/10.1017/S0953756203008840.

Rondón VM, González MR. 2009 - Micobiota endofítica asociada al cultivo del mango 'Haden' (Mangifera indica L.) en el oriente de Venezuela. Revista UDO Agrícola 9, 393-402. 
Santamaria J, Bayman P. 2005 - Fungal epiphytes and endophytes of coffee leaves (Coffea arabica). Microbial Ecology 50, 1-8. http://dx.doi.org/10.1007/s00248-004-0002-1.

Santos JS, Santos MLP, Conti MM. 2010 - Comparative study of metal contents in Brazilian coffees cultivated by conventional and organic agriculture applying principal component analysis. Journal of the Brazilian Chemical Society 21, 1468-1476. http://dx.doi.org/10.1590/S0103-50532010000800009.

Saunders M, Glenn AEG, Kohn LM. 2010 - Exploring the evolutionary ecology of fungal endophytes in agricultural systems: using functional traits to reveal mechanisms in $\begin{array}{llll}\text { community } & \text { processes. } & \text { Evolutionary }\end{array}$ http://dx.doi.org/10.1111/j.1752-4571.2010.00141.

Selim KA, El-Beih AA, AbdEl-Rahman TM, El-Diwany AI. 2011 - Biodiversity and antimicrobial activity of endophytes associated with Egyptian medicinal plants. Mycosphere 2, 669-678. http://dx.doi.org/10.5943/mycosphere/2/6/7.

Sutton BC. 1980 - The Coelomycetes. Commonwealth Mycological Institute, Kew, England. 696 p.

Vega FE, Posada F, Peterson SW, Gianfagna T, Chaves F. 2006 - Penicillium species endophytic in coffee plants and ochratoxin A production. Mycologia 98, 31-42. http://dx.doi.org/10.3852/mycologia.98.1.31.

Vega FE, Simpkins A, Aime MC, Posada F, Peterson SW, Rehner SA, Infante F, Castillo A, Arnold AE. 2010 - Fungal endophyte diversity in coffee plants from Colombia, Hawai'i, Mexico, and Puerto Rico. Fungal Ecology 3, 122-138. http://dx.doi.org/10.1016/j.funeco.2009.07.002.

Waller F, Achatz B, Baltruschat H, Fodor J, Becker K, Fischer M, Heier T, Huckelhoven R, Neumann C, Wettstein D, Franken P, Kogel K. 2005 - The endophytic fungus Piriformospora indica reprograms barley to salt-stress tolerance, disease resistance, and higher yield. Proceedings of the National Academy of Sciences of the United States of America 102, 13386-13391. http://dx.doi.org/10.1073/pnas.0504423102.

Wickert E, Goes A, Lemos EGM, Souza A, Silveira EL, Pereira FD, Rinaldo D. 2009 Phylogenetic relationships and diversity of Guignardia spp. isolated from different hosts on ITS1-5,8S-ITS2 region. Revista Brasileira de Fruticultura 31, 360-380. http://dx.doi.org/10.1590/S0100-29452009000200010. 